\title{
Meningkatkan Kesadaran Politik di Kalangan
}

\section{Anak Muda}

\author{
${ }^{(1)}$ Anisah Nasih Zulfa, ${ }^{(2)}$ Eka Putri Permata Sari, ${ }^{(3)}$ Anita Trisiana \\ ${ }^{1,2)}$ Mahasiswa Fakultas Keguruan dan Ilmu Pendidikan Prodi Bimbingan dan Konseling \\ Universitas Slamet Riyadi Surakarta \\ ${ }^{(3)}$ Dosen PPKn Universitas Slamet Riyadi Surakarta
}

\begin{abstract}
ABSTRAK
Politik mungkin sudah tak asing lagi di Indonesia. Polemik politik yang bermacammacam sering mejadi daya tarik tersendiri di masyarakat khususnya utuk para kaum muda Indonesia. Kaum milenial sering disebut pula sebagai cikal bakal penurus bangsa. Kaum muda sangat dibutuhkan bagi kemakmuran bangsa karena diharapkan para kaum muda ini mempunyai ide-ide yang kreatif untuk bisa merubah bangsa Indonesia menjadi lebih baik. Namun, sering kali juga kaum muda sekarang menjadi sasaran bagi pemain politik. Anak muda selalu diperebutkan politikus. Mendekati anak muda dengan segala cara, demi meraup suara para pemilih pemula. Cara pemikiran kaum muda yang belum matang dan terkesan masih labil sering dimanfaatkan. Terkadang pemikiran awam tentang politik oleh anak muda malah dijadikan point emas bagi mereka. Padahal kemuda bukan hanya sekedar tampilan, muda berarti juga kaya dengan berbagai terobosan. Apalagi anak muda yang notabeni berperan sebagai pemeran paradigma pembangunan bangsa yang senantiasa mengedepankan etika yang tercantum pada nilai-nilai luhur pancasila.Anak muda jangan hanya dianggap tambang suara belaka, tapi gunakanlah suara anak muda sebagai penyambung aspirasi demi pembangunan bangsa ini agar tetap dengan nilai - nilai yang terkandung dalam pancasila itu sendiri.
\end{abstract}

Kata Kunci : Politik, Pancasia, Anak Muda

\begin{abstract}
Politics may be familiar in Indonesia. Various political polemics often become the main attraction in the community, especially for Indonesian youth. Millennials are often referred to as the forerunners of the nation's management. Young people are very much needed for the prosperity of the nation because it is expected that these young people have creative ideas to be able to change the Indonesian nation for the better. However, often also young people are now targeted by political players. Young people are always contested by politicians. Approaching young people in all ways, to reap the voices of beginner voters. The way of thinking of young people who are immature and seemingly unstable is often used. Sometimes layman's thoughts on politics by young people are instead made a golden point for them. Even though youth is not just a display, young means also rich with various breakthroughs. Moreover, young people who are in charge act as role models for the nation's development paradigm that always prioritizes ethics that are stated in the noble values of the Pancasila. Young people should not only be considered mere sound mines, but use the voices of young people as connectors of aspirations for the development of this nation to remain with the values contained in the Pancasila itself.
\end{abstract}

Keyword: Politics, Pancasia, Youth 


\section{PENDAHULUAN}

Kualitas sumber daya manusia dapat menentukan nasib bangsa di masa depan. Sumber daya manusia yang baik tidak hanya dibentuk dengan pengetahuan saja, tetapi harus melibatkan partisipasi masyarakat dalam isu atau permasalahan yang berkaitan dengan politik.

Partisipasi politik masyarakat merupakan bentuk aktualisasi dari demokrasi dalam bentuk politik dan yang akan mendorong demokrasi berdasrkan nilai nilai demikrasi tersebut, antara lain nilai nilai demokrasi adalah sebagai berikut : Keterbukaan,kebebasan, dan aturan yang berlaku.

Konsep politik .ini sudah ada sejak dahulu pada pemikiran mannusia dan bersifat belum terlalu jelas.Konsep ini berfungsi untuk menyusun generasi tentang fenomena-fenomena yang diartikan teori.

Menurut Aristoteles, politik adalah usaha yang ditempuh warga negara untuk mewujudkan kebaikan bersama. Sedangkan menurut Prof. Miriam Budiardjo, politik adalah bermacammacam kegiatan yang menyangkut penentuan tujuan-tujuan dan pelaksanaan tujuan itu.

Berdasarkan kedua teori di atas, dapat diartikan bahwa usaha yang dilakukan itu bukan perilaku politik yang digunakan untuk menpengaruhi tentang pemaparan nilai individu yang dimaksudkan agar mempengaruhi pengambilan keputusan yang diambil

Sebagian masyarakat enggan terlibat dalam politik, sebab politik itu buruk. Namun, berbicara mengenai politik berarti sedang membicarakan perilaku setiap individu di dalam masyarakat secara keseluruhan. Partisipasi politik mendorong setiap individu untuk bertindak menegosiasikan kepentingan masingmasing agar kemudian melahirkan kesepakatan bersama tanpa merugikan pihak manapun.

Sangatlah menarik jika kita berbicara tentang politik, apalagi jika itu dari pemikiran anak muda negeri ini. Menurut kalian apa yang yang ada dibenak anak muda jika mendengar kata politik? Saya yakin pasti yang terbayang dikepala anak muda jika mendengar kata politik adalah soal rebutan kekuasaan, kolot, urusan orang tua, kebohongan publik, dan korupsi.

Mengapa pandangan kaum muda sebegitu negatifnya memandang politik yang dipratikkan di negeri ini?. Banyak anak muda di negeri ini memiliki persepsi negatif begitu mendengar kata politik. Dunia politik buatnya adalah dunia yang 
kelam, tempat para monster politik saling memangsa satu sama lain, termasuk memangsa rakyatnya sendiri. Pokoknya politik itu seram, jauh dari idealnya bahwa politik merupakan jalannnya untuk memperjuangkan kebaikan bersama, keadilan, kesejahteraan, dan kebebasan.

Banyak anak muda yang cenderung memandang politik sebagai cara untuk merebut kekuasaan semata. Para anak muda beranggapan bahwa politik identik dengan kekuasaan. Persepsi pandangan negatif terhadap politik di terjadi di negeri ini memang sulit dihindari. Bagaimana tidak, penyelewengan kekuasaan, kasus kasus korupsi perilaku tak etis politisi yang ada, dan hal - hal negatif lainnya dari dunia politik bisa dilihat secara blak blakan di segala media, termasuk media sosial yang menjadi bagian dari kehidupan kaum muda masa kini. Belum reda kekagetan kita mendengar satu kasus korupsi, kasus korupsi lainnya terkuak. Dan sebagian besar kebanyakan pelaku korupsi tersebut punya latar belakang partai politik. Begitu seterunya. Itulah realita politik yang ditangkap oleh anak muda. Wajar jika anak muda geram terhadap perilaku sebagian pelaku politik yang tidak etis dan korup. Terlalu banyak drama dari para pelaku politik yang ditunjukkan dipublik yang banyak membuat anak muda menjadi enggan berpolitik.

Ini semestinya menjadi menjadi peringatan bagi para pelaku politik. Bagaimanapun, posisi kaum muda yang sering disebut dengan generasi milenial ini cukup menentukan karna jumlah anak muda di negeri ini yang tidak sedikit. Oleh karena itu suara mereka harus didengar dan harus menjadi perhituangan bagi para pelaku politik.

Persoalan - persoalan lain yang menyangkut politik yamg membuat anak muda khawatir adalah marakya tulisan yang bersifat provokatif dan kampanye hitam dimedia sosial. Tentuanya mereka merasa marah sekaligus takut dengan informasi hoax. Menurut mereka, jika tulisan provokatif atau hoaks tentang politik kian menyebar, semakin banyak pula orang yang akan merasa curiga atau saling membenci.

Hal itu pula yang akan menjadikan pepecahan di antara kaum muda. Bagaimana kaum muda bisa disebut dengan pembanguan bangsa jika anak muda di negeri ini malah saling menyalahkan satu dengan yang lain.

Jangan gunakan suara anak muda hanya untuk tambang suara saja. Sekarang ini, banyak para pelaku politik yang berlomba - lomba bisa memikat suara para 
anak muda hanya demi memenamgkan partai politiknya saja. Banyak dari para pelaku politik yang tak sungkan bergaya kekinian demi memikat hati anak muda negeri ini.

Banyak pula para pelaku politik yang masih menggunakan strategi lama. Hanya mengumbar - umbar janji palsu. Anak muda negeri ini harus bisa memilah dengan seksama agar tidak terjerumus dengan janji - janji tersebut. Namun, tak jarang pula ada beberapa dari partai politik yang memasukan anak muda menjadi anggota di partainya. Hal ini dimaksutkan mungkin dengan memasukan anak muda didalamnya bisa mengubah pandangan anak muda tentang negatifnya sistem politik dinegeri ini. Keberadaan partai politik dinilai sebagai alat yang dapat menyadarkan masyarakat melalui peran politiknya. Partai politik mulai menyadari akan pentingnya memperhatikan anak muda sebagai potensi pemilih suara dari kalangan ini.

Kalangan anak muda memberikan keuntungan bagi partai politik apabila masukan pendidikan politik pada kalangan ini diberikan secara intensif sebab kesadaran berpolitik yang tinggi dan demokrasi dalam proses politik pasti akan terwujud. Pendidikan politik penting bagi anak muda karena mereka adalah generasi pemilih di masa yang akan datang.

Pemikiran anak muda yang mempunyai ambisi ingin maju dan berkembang bisa menjadi acuan sistem politik dinegeri ini. Banyak anak muda yang ingin mengubah negeri ini melalui sistem politik yangada.

Sebenarnyamedia sosial dapat dimanfaatkan untukberpartisipasi bagi kaum muda, namun sampai saat ini untuk partai politik itu sendiri, sosial media hanya digunakan sebagaitempat berpartisipasi ,sedangkan terlalu rumit jika dijadikan pondasi untuk melaksanakan kegiatan yang benar-benar terjadi.

Maka dari itu bnayak anak muda yang memandang politik dinegeri ini dengan cara yang sadis, seperti sebagai sarang koruptor, sarang nepotisme, dan sejenisnya. Sudah sangat jelas, itulah alasan bagi kaum muda harus bisa melakukan perubahan dan reformasi sistem politik secara signifikan dan nyata..

Pada realita yang terjadi pada sangat ini bahwa politik dapat dilakukan dengan jujur. Sebagai contoh kegiatan politik dalam pemilu dapat dilakukan dengan cara ikut terlibat dalam proses pemilu tersebut .Masalah politik yang masih buruk dapat dirubah oleh para 
pemuda dengan tujuan untuk memperbaiki politik kedepannya .

Beberapa anak muda pada zaman sekarang sudah masuk dalam partai politik tetapi kebnayakan anak tersebut tidak konsisten dengan satu partai politik ,mereka masih mudah berpindah pindah dari satu partai politik ke partai politik lain .Para anak muda itu belum mempunyai pendirian karena belum adanya wawasan dan beluum begiitu paham tentang politik .Ada juga anak muda yang mengikuti partai politik hanya untuk mencari kekuasaan dengan begitu mereka tidak dapat bekerja dengan baik dan menjalankan amanat yang diberikan kepada mereka .Perilaku anak muda tersebut akan bertentangan dengan idelogi pancasila sebab mereka hanya mementingkankepentingan pribadi dan menggunakan politik sebagai alat untuk mencapai apa yang diinginkan .Seharusnya sebagai anak muda yang akan menjadi penerus bangsa mereka harus mempunyai nilai moral yang baik, idealism yang dapat dapat digunakan sebagai panduan dalam berpolitik.

\section{METODE}

Dalam penulisan ini digunakan tipe penelitian deskripti kualitatif ,Menurut Nazir\{1988:63\} dalam Buku Contoh Metode Penelitian, metode deskriptif merupakan suatu metode dalam meneliti status sekelompok manusia ,suatu objek ,suatu sel kondisi ,suati sistem pemikiran ,ataupun suatu kelas peristiwa pada masa sekarang .Tujuan dari penelitian deskriptif ini adalah untuk membuat deskripsi,gambaran,atau lukisan secara sistematis ,factual ,dan akurat mengenai fakta -fakta sifat-sifat serta hubungan antar fenomena yang diselidiki

Sedangkan menurut Sugiyono \{2001:6\}'Penelitian deskriptif adalah penelitian yang dilakukan terhadap variable mandiri,yaitu tanpa membuat perbandingan atau menghubungkan variable yang lain".

\section{PEMBAHASAN}

\section{Pengertian Politik}

Untuk memahami politik, sebaiknya kita terlebih dahulu mengetahui arti dari politik itu sendiri. Dalam catatan sejarah, orang yang pertama mengenalkan kata politik adalah Aritoteles (384 - 322 SM) seorang filsuf Yunani Kono. Ia mengemukaan, bahwa "manusia adalah merupakan binatang poitik, atau political animal". Melihat dari penjelasan tersebut , ia menerangakan bahwa hakikat kehidupan sosial sesungguhnya merupakan politik, karena interaksi satu sama lain dari dua atau lebih orang sudah pasti akan melibatkan hubungan politik. 
Apabila ada seseorang yang ingin meraih kesuksesanya dengan tujuan kepentingan pribadi dengan melalui kegiatan politik. Atas dasar itulah Aritoteles berkesimpulan bahwa upaya untuk memaksimalkan kemampuan seorang invidu degan tujuan untuk mencapai kehidupan social yang berlebih melalui interaksi social yaitu interaksi politik dengan orang lain dalam suatu badan kelembagaan.

Kala itu Aritoteles menyebutnya dengan kata "Polis". Polis diambil dari kata polistaia, polis berarti "kesatuan masyarakat yang berdiri sendiri (negara)" dan taia yang berarti "urusan". Jadi, polis adalah suatu lembaga yang memiliki kekuasaan untuk mengurus kesatuan masyarakat dalam menciptakan suasana yang tertib dalam kehidupan bersama disuatu wilayah negara tersebut .

Diambil dari kata polis ,politik dapat digunakan untuk acuan dalam mengatur hidup masyarakat yang berhub ungan dengan masalah tentang pran pemerintahan dalam menjalankan politik dengan baik agar terciptanya kehidupan masyarakat politik atau negara yang paling baik.

Jadi, dalam politik ini terdapat berbagai aspek ,yaitu lembaga yang menjalankan kegitan pemerintahan ,dan masyarakat yang digunakan sebgai pihak yang berkepentingan serta peraturan peraturan hukum yang digunakan untuk menampung berbagi cita -cita yang hendak dicapai bersama.

Berangkat dari kata polis tersebut, diturunkan beberapa kata - kata lainnya, seperti : politeia, polities, politicos, politica, politike tekne, politike episteme. Beberapa kata turunan dari kata lembapolis tersebut telah berkembanng menjadi kata dan pengertian dalam berbagai bahasa, antara lain bahsa inggris seperti polity, politic, polities, political, politician, dan policy.

Pemahaman politik yang masih tekesan kabur seperti itu, maka perlu adanya kejelasan pengertian "politik" untuk menghindari salah tafsir, agar orang mendapat visi yang jelas dan sistematis mengenai realita politik. Oleh karena itu, perlu dirumuskan beberapa definisi politik secara benar.

Budiardjo menyatakan bahwa pengertian politik adalah: "Pada umunnya dikatakan bahwa politik (politic) adalah bermacam - macam kegiatan dalam suatu sistem politik (atau negara) yang menyangkut proses menentukan tujuan tujuan dari sistem itu dan melaksanakan tujuan - tujuan itu. 
Dari berbagai pengertian politik diatas tampak ada perbedaan. Perbedaan itu disebabkan karena setiap sarjana cenderung meneropong hanya salah satu aspek atau unsur politik. Kemudian unsur tersebut diperlakukan sebagai konsep pokok yang dipakai untuk meneropong unsur-unsur lainnya. Konsep-konsep yang dimaksud adalah: negara (state), kekuasaan (power), pengambilan keputusan (decion making) kebijakan (policy), pembagian (distribution), atau alokasi (alocation).

\section{Partisipasi Politik Masyarakat}

Partisipasi politik merupakan suatu masalah yang penting, dan akhir - akhir ini banyak dipelajari terutama dalam hubungannya denga negara - negara berkembang. Pada awalnya studi mengenai partisipasi politik memfokuskan diri pada partai politik sebagai pelaku utama, tetapi dengan berkembangnya demokrasi banyak muncul kelomok masyarakatbyang juga ingin mempengaruhi proses pengambilan keputusan mengenai kebijakan umum.

Apakah partisipasi politik itu? Sebagai defisi umum dapat dikatakan bahwa partai politik adalah kegiatan seseorang atau sekelompok orang untuk ikut serta secara aktif dalam kehidupan politik, antara lain dengan jalan lain memilih pimpinan negaradan, secara langsung atau tidak langsung, mempengaruhi kebijakan pemerintah.

Di negara - negara demkrasi konsep partisipasi politik bertolak dari paham bahwa kedaulata ada ditangan rakyat, yang dilaksanakan melalui kegiatan bersama untuk menentukan tujuan - tujuan serta masa depan masyarakat itu dan untuk menentukan orang - orang yang akan memegang tampuk pimpinan. Jadi, partisipasi politik merupakan pengejawatan dari penyelenggaraan kekuasaan politik yang absah oleh rakyat.

Anggota masyarakat yang berpartisipasi dalam proses politik, misalnya melalui pemberian suara atau kegiatan lain, terdorong oleh keyakinan bahwa melalu kegiatan bersama itu kepentingan mereka akan tersalurkan atau sekurang - kurangnya dioerhatikan, dan bahwa merekan sedikit banyak dapat memengaruhi tindakan dari mereka yang berwenang untuk membuat keputusan yang mengikat. Dengan kata lain, mereka percaya bahwa kegiatan mereka mempunyai efek politik.

Jelasnya, bahwa partisipasi politik erat sekali dengan kesadaran politik, karena semakin sadar bahwa dirinya diperintah, orang kemudian menuntut diberikan hak bersuara dalam penyelenggaran pemerintah. Di negara 
demokrasi seperti negara Indonesia ini umumnya dianggap bahwa lebih banyak partisipasi masyarakat, lebih baik. Sebaliknya, tingkat partisipasi yang rendah pada umunya dianggap sebagai tanda yang kurang baik, karena dapat ditafsirkan bahwa banyak masyarakat tida menaruh perhatian terhadap masalah kenegaraan.

Berbicara mengenai partisipasi, berarti juga membicarakan persoalan kerelawanan. Yang menarik pada pemilihan presiden Republik Indonesia lalu, yakni banyak sekali relawan yang berasal dari kalangan anak muda. Hal ini bertentangan dengan teori Geronthocracy, yaitu demokrasi itu berada di tangan orang tua dan anak muda hanyalah pengikut. Indonesia mencatat bagaimana anak muda menempati daerah kekuasaan pada usia yang masih muda.

Dalam hubungan ini mungkin dapat dikatakan bahwa dalam hampir setiap kegiatan partisipasi ada unsur tekanan atau manipulasi, di negara - negara berkembang terdapat kombinasi dari unsur sukarela dan unsur manipulasi dengan berbagai bobot dan takaran. Ada pula yang menganggap bahwa partisipasi politik hanya mencangkup kegiatan yang bersifat positif.

Disamping mereka yang ikut serta dalam satu atau lebih bentuk partisipasi, ada juga masyarakat yang sama sekali tidak melibatkan diri dalam kegiatan politik. Hal ini adalah kebalikan dari partisipasi dan disebut apati (apathy).

Timbul pertanyaan: mengapa orang apatis? Ada beberapa jawaban. Meraka tidak ikut berpartisipasi karena sikap acuh tak acuh dan tidak tertrik pada, atau kurang paham dengan masalah politik. Ada juga karena tidak yakin bahwa usaha untuk mempengaruhi kebijakan pemerintah akan berhasil, dan ada juga yang sengaja tidak memanfaatkan kesempatan memilih karena kebetulan berada dilingkungan dimana ketidaksertaan merupakan hal yang dianggap biasa.

Ada kemungkinan bahwa orang tidak ikut serta memilih karena perpendapat bahwa keadaan tidak terlalu buruk dan bahwa siapa pun yang akan dipilih tidak akan mengubah keadaan itu. Dengan demikian ia tidak merasa perlu memanfaatkan hak pilihnya. Jadi,"apatis" dalam pandangan ini tidak merunjuk pada rasa kecewa atau frustasi, tetapi bisa sebagai manifestasi dari rasa puas dan kepercayaan terhadap sistem politik yang ada.

Partisipasi politik dapat digunakan dalam menunjukan berbagai bentuk politik dindonesia dan intensitas politik yang baik .Apabila ada seseorang yang mengikuti 
kegiatan secara rutin ,sebagai contoh kegiatan yang tidak memerlukan waktu yang banyak adalah pada saat pemberiaan suara pada saat pemilu

Keberadaan partai politik dinilai sebagai alat yang dapat menyadarkan masyarakat melalui peran politiknya. Partai politik mulai menyadari akan pentingnya memperhatikan anak muda sebagai potensi pemilih suara dari kalangan ini.

\section{Pentingnya Partisipasi Politik di}

\section{Kalangan Anak Muda}

Kalangan anak muda memberikan keuntungan bagi partai politik apabila masukan pendidikan politik pada kalangan ini diberikan secara intensif sebab kesadaran berpolitik yang tinggi dan demokrasi dalam proses politik pasti akan terwujud. Pendidikan politik penting bagi anak muda karena mereka adalah generasi pemilih di masa yang akan datang.

Ketidak ikut serta dalam proses pemilihan umum karena siapa pun yang akan terpilih nantinya tidak akan mampu mengubah bangsa ini menjadi lebih baik, korupsi di mana-mana dan hak suara yang digunakan dapat dikatakan menjadi sia-sia.

Berangkat dari opini tersebut, terbersit untuk berpikir kembali akan pentingnya partisipasi politik dalam mewujudkan demokrasi politik. Sudah sepantasnya anak muda membuka wawasan politik agar apapun opini publik yang diberikan terkait proses politik jangan diterima begitu saja secara mentah. Lihat sisi lainnya, sebab satu suara dalam pemilihan umum akan menentukan ke mana arah bangsa ini nantinya.

Memilih bukanlah hal yang mudah, namun tidak memilih bukanlah sikap yang bijak. Anak muda juga memiliki peran politiknya. Tugas partai politik adalah melibatkan kalangan anak muda melalui program-program yang terorganisir.

Pendidikan sekolah juga memiliki peran penting dalam upaya pengenalan tentang dunia politik dikalangan anak muda.Pemberian Pendidikan tentang politik sangat diperlukan untuk memberikan wawasan dan pengajran untuk generasi muda tentang politikyang digunakan sebagai dasar yang berfungsi untuk mencapai kebijakan bersama. Pendidikan sangat berperan dalam memberikan pengetahuan tentang pentingnya politik dan partisipasi politik. Bagi generasi kedepan .

Kita sangat memerlukan generasi anak muda yang bersedia ikut berjuang bersama demi kemajuan negara melalui politik.Anak muda yang dapat mempengaruhi sikap partai politiksupaya lebih baik dan generasi mudamuda yang 
kemudian mampu berbuat sesuatu yang besar untuk bangsa Indonesia, untuk seluruh masyarakat Indonesia, dan generasi-generasi selanjutnya dimasa yang akan datang. Tak salah rasanya harapan ini, bahwa mustahil rasanya berdemokrasi tanpa partai politik. Memang pada awalnya pasti akan banyak tantangan, halangan, ataupun godaan, tapi itulah bagian dari perjuangan.

Harapan bagi anak muda dengan semangat yang begitu tnggi ,mampu melakukan sesuatu bagi Indonesia dalam merubah politik diindonesia ini, dengan begitu partai politik akan mempunyai motivasi baru untuk menjalankan fungsi dan tugasnya dengan baik dan tidak berlandas pada kepentingan pribadi.Oleh sebab itu akan muncul rasa antusias dalam mewujudkan demokrasi,

Generasi muda pada saat ini akan terus menyesuaikan diri dengan perubahan zaman sekarang untuk mengikuti era duni politik yang terus berkembang dengan pesat. Generasi muda harus menyadari bahwa dalam berpolitik kekuasaan yang berlebih itu tidak baik kaena berpolitik tidak hanya soal kekuasaan tetapi mengemban sebuah amanat yang besar dalam kehidupan negra dan bermsayrakat.

Tetapi dalam persoalan ini banyak geberasi muda yang mementingkan kepentingan pribadinya teerhadap partai politik dengan hal itu proses politik akan pindah ke tempat yang lain, dalam pengajran politik dapat dilakukan dengan menggunakan media social karena media social lebih banyak digunakn dan lebih terupdate daripada dari Koran karena kebanyakan orang malas membaa kabar atau informasi dari sebuah Koran atau buku .

Ada sebuah kata bijakyang berkata, "setiap manusia ada masanya"? Seharusnya kita harus yakin, apabila anak muda dapatberpegang teguh dalammemperjuangkan sesuatu , maka mimpi dan aspirasi yang dimilikinya tentu akan mendapat balasan yang setimpal.. Anak muda yang akan menjadi genasi penerus bangsa akan senang dalam menyambut kepemimpinan baru pada saat ini Oleh sebab itu akan terjadi perubahan dalam politik yang akan berubah kearah yang lebih baik dan itu yang akan menjadi semangat generasi muda dalam berjuang untuk bangsa indonesi ini dan melahirkan generasi yang berguna bagi bangsa dan bernegara dengan kepemimpinan yang baik dan jujur dalam berpolitik .

Terciptanya politik dan demokrasi yang baik itu semua bergantung didalam tangan anak muda sebagi generasi bangsa Indonesia untuk masa depan yang 
gemilang.Untuk upaya memperbaiki sistem politik ini generasi muda dapat melirik partai politik untuk tempat awal perjuangan mereka untuk memperbaiki demokrasi .

Jika semua harapan itu bisa terealisasikan,maka kita tidak akan melihat pertentangan politik pada era sekarang ataupun era lama .Seharusnya generasi sekarang dan generasi lama harus saling berkomunikai dalam memperbaiki politik dan guan bias merubah sistem politik ini kearah yang lebih baik, dengan tujuan untuk mempersiapkan kepemimpinan nasional yang baik suapaya sistem perubahan dapat dilakukan dengan baik dan sesuai aturan hukum tanpa melibatka kepentingan pribadi karena politik merupakn kerjasama untuk kepentingan bersama dalam masyarakat ,negara dan berbgsa deng tujuan menyejahterakan politik Indonesia dan bersih dari hal -hal yang menyimpang hukum .

\section{PENUTUP}

\section{Simpulan}

Untuk berpikir kembali akan pentingnya partisipasi politik dalam mewujudkan demokrasi politik. Sudah sepantasnya anak muda membuka wawasan politik agar apapun opini publik yang diberikan terkait proses politik jangan diterima begitu saja secara mentah. Lihat sisi lainnya, sebab satu suara dalam pemilihan umum akan menentukan ke mana arah bangsa ini nantinya.

Memilih bukanlah hal yang mudah, namun tidak memilih bukanlah sikap yang bijak. Anak muda juga memiliki peran politiknya. Tugas partai politik adalah melibatkan kalangan anak muda melalui program-program yang terorganisir.

Tentunya partisipasi dan kesadaran akan pentingnya politik bagi kalangan anak muda harus dilandasi oleh hasrat untuk mencapai tujuan bersama (public goods). Oleh karena itu, mulai dari sekarang, anak muda Indonesia harus aktif berpolitik, boleh dengan ikut serta dalam pemilih umum atau menyampaikan aspirasinya tentu tidak dengan kekerasan, agar demokrasi berkualitas dapat terwujud dan bisa melahirkan sitem pemerintahan yang lebih baik.

\section{Saran}

Karena pada tahun 2019 kita akan memasuki tahun politik. Tensi politik kemungkinan akan memanas. Kaum muda sangat mengingikan agar arena politik dikembalikan pada posisinya yang ideal, yakni jalan untuk mencapai kehidupan bersama yang lebih baik. Saya selaku salah satu anak muda setuju jika tujuan orang berpolitik seharusnya untuk membantu 
meningkatkan kesejahteraan rakyat, bukan hanya bertujuan mengejar kekuasaan dan uang.Untuk para pelaku politik, kesampingkanlah ego kalian, dengarkan apa yang menjadi kebutuhan masyarakat demi bisa mensejahterakan kita.

Kita selaku anak muda juga harus pandai-pandai dalam ,memilih calon pemimpin negeri kita. Jangan memilih calon pemimpin yang cacat atau pernah melakukan korupsi. Politik sejatinya bukan hanya soal kontestasi dan kekuasaan

\section{DAFTAR PUSTAKA}

Aminah, S. (1999). Politik Media,

Demokrasi dan Media Politik. Ilmu

Politik FISIP Unair

Budiardjo. (1983). Perkembangan Ilmu

Politik Di Indonesia. Jakarta: Ghalia

Indonesia

Budiardjo, M. (2008). Dasar-Dasar Ilmu

Politik. Jakarta: PT Gramedia Pustaka Utama

Karman, M. M. (2006). A Critique on

Waltz's Interpretation of Roussesau. Cambridge University Press kekuasaan semata. Politik terwujud dalam keseharian dan kehidupan sehari hari. Selain berpartisipasi dalam pemilu, kita anak muda bisa melakuakan banyak hal, seperti ikut mengartikulasikan kepentingan orang banyak, mengadvokasikan dan mendampingi kaum yang terpinggirkan lewat tulisan, musik, film, kegiatan sosial, dan sebagainya. Kita sebagai anak muda jangan hanya sebagai pengikut. Secara historis, anak muda adalah kaum yang terlibat dan berpengaruh.
Kushandajani. (2010). Ilmu Politik. Universitas Diponegoro

Maksudi, B. I. (2012). Sistem Politik Indonesia. Jakarta: PT Rajagrafindo Persada

Mega Sri AyuFelisia,A. Trisiana,(2018)

"Penguatan Pancasila Dalam

Perbuatan (Alternatif Tindakan Koratif di Era Globalisasi )." Global Citizen. Vol 4 2018, pp. 14-29.

Meyer, T. (2012).Peran Partai Politik Dalam Demokrasi. Jakarta: PT.FES 
Sjamsuddin, N. (1993). Dinamika Siistem

Politik Indonesia. Jakarta: PT

Gramedia Pustaka Utama

Tyas, F. S. (2014). Peran Orang Tua

Dalam Menanamkan Keasadaran

Politik Kepada Anaknya. Universitas

Negeri Semarang,

Wartoyo, A.Trisiana. (2017). Integrasi

Pendidikan Karakter dalam

Pembelajaran Pendidikan

Kewarganegaraan untuk

Meningkatkan Kedisiplinan

Mahasiswa Universitas Slamet Riyadi.

Global Citizen. Vol 4 2017, pp.47-64.

Yuliantina, M. (2016). Pengaruh

Kesadaran Politik Dalam Pemilu.

Fakultas Ilmu Pemerintahan, 16-34. 